\title{
Biotreatment of Soil Contaminated with Spent engine Oil by Locally Isolated Microorganisms
}

\author{
Ayandele, Abiodun A \\ Department of Pure and Applied Biology, Ladoke Akintola University of Technology, P M B, Ogbomoso, Oyo State, Nigeria
}

Correspondence Author: Ayandele, Department of Pure and Applied Biology, Ladoke Akintola University of Technology, P M B , Ogbomoso, Oyo State, Nigeria

E-mail: aayandele@lautech.edu.ng

Received date: 8 July 2018, Accepted date: 25 July 2018, Online date: 25 November 2018

Copyright: (C) 2018 Ayandele et al., This is an open-access article distributed under the terms of the Creative Commons Attribution License, which permits unrestricted use, distribution, and reproduction in any medium, provided the original author and source are credited.

\begin{abstract}
Bioremediation is an eco-friendly process that makes use of microorganisms to break down hazardous compounds like hydrocarbons into simpler and innocuous compounds. In this study, hydrocarbon degrading microorganisms were isolated from contaminated soil samples. Isolated microorganisms were identified and screened for their biodegradation abilities in aerobic conditions. The soil samples were contaminated with $5 \%(\mathrm{w} / \mathrm{v})$ of spent engine oil and total heterotrophic bacteria count (THBC) and total hydrocarbon degrading bacteria count (THDBC) were determined by plate count method, while physicochemical and heavy metals properties of the soil samples were analysed by titrimetric and atomic absorption Spectrophotometry respectively. Gravimetric analysis was used to determine Total Petroleum Hydrocarbon (TPH) after treatment with test organisms. THBC and THDBC ranged from $175-280 \times 10^{5} \mathrm{CFU} / \mathrm{g}$ and $47-95 \times 10^{3} \mathrm{CFU} / \mathrm{g}$ respectively for the control plot, while THBC ranged from $197-275 \times 10^{3} \mathrm{CFU} / \mathrm{g}$ and THDBC was $180-473 \times 10^{5} \mathrm{CFU} / \mathrm{g}$ for the contaminated plot. Six microorganisms; Pseudomonas aeruginosa, Micrococcus sp, Flavobacterium sp, Rhizopus sp, Penicillium sp and Fusarium sp were isolated from hydrocarbon contaminated sites. The results obtained from the greenhouse experiment showed a significant decrease (at $\mathrm{p} \leq 0.05$ ) in the nutrients content of the soil samples. There was an increase from 1.09 in the negative control to $15.5 \%$ in the content of organic matter after contamination and from $1.88 \%$ to $26.8 \%$ in the $\%$ of organic matter too. There was a significant reduction (at $\mathrm{p} \leq 0.05$ ) in the concentration of $\mathrm{Fe}, \mathrm{Zn}, \mathrm{Pb}, \mathrm{Cd}$, $\mathrm{Cu}, \mathrm{Cr}$ and $\mathrm{Ni}$ after 10 weeks of treatment with the tested organisms, but increase in $\mathrm{pH}$ values was observed in all the treatments. The TPH degradation (\% loss) ranged from 79.7\% - 89.2\% after 10 weeks of treatment. P. aeruginosa had the highest level of degradation (89.2\%), while Micrococcus sp and Rhizopus sp had the least degradation of $79.9 \%$.

This study showed that all the bacteria isolated from the spent engine oil contaminated soil were able to degrade the spent engine at concentration of $2 \%(\mathrm{w} / \mathrm{v})$. Soil samples also supported the growth of Zea mays after six weeks of treatment. Therefore, all the isolated bacteria can be used in biodegradation experiment.
\end{abstract}

Key words: Bioremediation, physicochemical, total hydrocarbon petroleum, heavy metals, Zea mays

\section{INTRODUCTION}

Engine oil could simply be defined as a thick mineral liquid applied to a machine or engine so as to reduce friction between the moving parts of the machine [1]. Used engine oil as the name implies represents oil that has undergone destructive changes in the property when subjected to oxygen, combustion gases, and high temperature. The said oil also undergoes viscosity changes as well as additive depletion and oxidation [2]. Used engine oil is derived after use and then drained out of the car engine during servicing [3]. Used engine oil is a pollutant of great concern because large volume of it is disposed into both aquatic and terrestrial ecosystem yearly [4].

In Nigeria, it is a common practice among motor mechanics to dispose off spent engine oil into gutters, water drains and soil [5; 6]. Spent engine oils contain a high percentage of aromatic and aliphatic hydrocarbons, nitrogen, sulphur compounds, and metals $(\mathrm{Zn}, \mathrm{Pb}, \mathrm{Cr}$ and $\mathrm{Fe})$ than fresh oils. Some of these metals in used engine oil can dissolve in water and move through the soil easily and may be found in surface water and groundwater [7; 8]. Spent engine oil causes great damage to soil and soil microflora. It creates an unsatisfactory condition for life in the soil due to poor aeration, immobilization of soil nutrients and lowering of soil $\mathrm{pH}$ [9]. It has been shown that marked changes occur in soil contaminated with hydrocarbons and these changes affect the physical, chemical and microbiological properties of the soil [5]. Other effects of used engine oil on soil include depletion of nutrients especially nitrogen and phosphorus and inhibition of microbial activities [10]

Microbial degradation is the major mechanism for the elimination of used petroleum products from the contaminated environment [11]. Microbial transformation and degradation is one of the best methods used in elimination of hydrocarbons from the contaminated environments [12, 13]. Soils contain very large numbers of microorganisms which can include a number of hydrocarbons utilizing bacteria and fungi [8]. Microorganisms are capable of breaking down many complex molecules by adaptation of their degradative enzyme system [9]. Bioremediation is, therefore, the application of a naturally occurring process by which microorganisms transform environmental contaminants into harmless end products [8]. Microorganisms such as Bacillus, Corynebacterium, Pseudomonas, Rhodococcus, Micrococcus and fungal species that include Fusarium sp, Penicillium, Aspergillus, Articulosporium species can utilize hydrocarbons oil as the sole source of energy and carbon $[14 ; 15 ; 16]$.

Therefore, this study was carried out to determine the biodegradation ability of fungi and bacteria isolated from used engine oil contaminated soil and the effects of bioremediation on the physicochemical properties and heavy metals present in the contaminated soil. 


\section{MATERIALS AND METHODS}

\section{Field Work:}

Four experimental plots $\left(1.0\right.$ by $\left.1.0 \mathrm{~m}^{2}\right)$ were mapped out in the garden for this experiment. Two plots were contaminated with $3 \mathrm{~L}$ of spent engine oil and mixed thoroughly up to a depth of $10 \mathrm{~cm}$, while the remaining two plots which were not mixed with spent engine oil served as a control. The soil samples were mixed together for aeration and watered every 3 days. Determination of Total Oil-Degrading bacteria and Total Heterotrophic bacteria counts were also carried out for a period of nine months. Tze-e yellow maize seeds collected from the International Institute of Tropical Agriculture (IITA), Ibadan, Nigeria, were planted on each plot after two weeks of contamination. Maize plant heights were measured in $\mathrm{cm}$ and monitored for a period of one month. The experimental months fell within the two common weather seasons (dry and rainy) in Nigeria.

\section{Isolation of Microorganisms:}

\section{Total Heterotrophic Bacteria (THB) Counts:}

A THB count was determined by pour plate method. Serial dilution was carried out on the soil sample collected from each plot and $1 \mathrm{ml}$ of the aliquot from each of the dilution was inoculated by pour plate method onto Nutrient Agar plates in triplicates [17]. The plates were incubated at $37^{\circ} \mathrm{C}$. THB counts were determined after $24 \mathrm{hrs}$ of incubation.

\section{Total Hydrocarbons Degrading Bacteria Counts (THBC):}

Spent engine oil was collected from a mechanic workshop and sterilized by using Millipore filter. $1 \mathrm{ml}$ of an aliquot of serially diluted soil sample was added onto Bushnell Hass agar containing $2 \mathrm{ml}$ of spent engine oil by spread plate method. The plates were incubated at $25^{\circ} \mathrm{C}$ and THDB counts were determined after 7 days of incubation.

\section{Screening for Spent Engine Oil Degraders:}

Nutrient and Potato Dextrose Agar were used for the isolation of bacteria and fungi respectively from contaminated soil samples. Pour plate method was also used as described by [17]. Pure bacterial and fungal isolates were then streaked on oil agar medium to determine those isolates that can utilize spent engine oil as their sole source of carbon. The oil agar medium consisted of basal (Mineral Salts) medium; $1.8 \mathrm{~g} \mathrm{~K}_{2} \mathrm{HPO}_{4}, 1.02 \mathrm{~g} \mathrm{KH}_{2} \mathrm{PO}_{4}, 4.0 \mathrm{~g} \mathrm{NH} \mathrm{Nl}_{4}, 2.0 \mathrm{~g} \mathrm{MgSO} \mathrm{g}_{4} .7 \mathrm{H}_{2} \mathrm{O}, 0.1 \mathrm{~g}$ $\mathrm{NaCl}, 0.1 \mathrm{~g}$ Yeast extract, $0.05 \mathrm{~g} \mathrm{FeCl}_{2}$ and trace elements consisting of $0.1 \mathrm{~g} \mathrm{H}_{3} \mathrm{BO}_{3}, 0.1 \mathrm{~g} \mathrm{ZnSO}$ and $0.4 \mathrm{~g} \mathrm{MnSO}_{4} \cdot \mathrm{H}_{2} \mathrm{O}$ in $1 \mathrm{~L}$ of sterile distilled water [18]. Those isolates that showed good growth on oil agar medium were used for biodegradation experiment.

\section{Characterization of Bacterial and Fungal Isolates:}

Microscopic and biochemical tests were used for identification of bacterial isolates and the isolates were characterized as described by Bergey's Manual of Determinative Bacteriology [19]. While both macroscopic and microscopic analyses were carried out on fungal isolates to determine their identities according to [20].

\section{Greenhouse Studies:}

\section{Preparation of Seed Bags:}

Each seed bag contained $1.5 \mathrm{~kg}$ of sterilized soil mixed with $300 \mathrm{~mL}$ of spent engine oil at a ratio of $1: 1 \mathrm{w} / \mathrm{v}$. Many seed bags were prepared for this experiment. Sterilized soil without spent engine oil was prepared to serve as positive control.

\section{Preparation of Inocula Treatment and Seedling:}

Three bacterial and fungal isolates each were used for this experiment. Bacteria and fungi were inoculated into plates containing Nutrient and Potato Dextrose agar respectively for $48 \mathrm{hrs}$. Isolates were centrifuged for 20 minutes, the supernatant was decanted, the cells washed and resuspended in sterile saline water $(0.9 \%)$. Bacterial and fungal cells were standardized by using Spectrophotometer. $100 \mathrm{~mL}$ of each isolate was mixed separately with soil sample and sterilized spent engine oil in each seed bag.

Seed bag containing sterile soil sample devoid of microorganisms and used engine oil served as positive control and was coded PC,

Seed bag containing sterilized soil and spent engine oil but devoid of microorganisms served as negative control and coded NC,

Seed bag containing sterilized soil and spent engine oil with each of $1^{\text {st }}, 2^{\text {nd }}$, and $3^{\text {rd }}$ bacterial isolates were coded BS1, BS2, and BS3 respectively,

Seed bag containing sterilized soil and spent engine oil with each of $1^{\text {st }}, 2^{\text {nd }}$, and $3^{\text {rd }}$ fungal isolates were coded FS1, FS2, and FS3 respectively. All the treated soil samples and both the positive and negative control soil samples were prepared in triplicate.

Changes in Total Petroleum Hydrocarbons levels, physicochemical and heavy metal analyses were determined during the 10 weeks of the experiment.

\section{Planting of Maize Seeds}

Four viable seeds of Tze-e yellow maize were planted in each of the seed bags for ecotoxicity test after six weeks of treatment. Germination of maize seeds was monitored and plant heights were measured in $\mathrm{cm}$ and recorded for a period of three weeks. Watering of seed bags was carried out at every 5 days interval.

\section{Physicochemical Analyses:}

Soil $\mathrm{pH}$ was determined by using a $\mathrm{pH}$ meter. Calcium and Magnesium were determined by titrimetric method [21]. Total Nitrogen was determined by Kjeldahl digestion and steam distillation method [22]. Available Phosphorus was also determined according to the method of [23], while Potassium was also determined by using the Flame photometer [21].

\section{Determination of Total Organic Carbon and Organic Matter:}

The soil sample is sieved through $1 \mathrm{~mm}$ sieve and $1 \mathrm{~g}$ of sieved soil sample was put in a $100 \mathrm{~mL}$ flask. $10 \mathrm{~mL}$ potassium dichromate and $20 \mathrm{~mL}$ sulphuric acid were added to the sample and shaken very well. The mixture is allowed to cool on the asbestos sheet and the volume is made up of $100 \mathrm{mLwith}$ distilled water and kept overnight. The optical density was measured at $660 \mathrm{~nm}$ wavelength using a spectrophotometer.

$\%$ Organic Carbon $=$ optical density $\times$ Factor F

$\%$ Organic Matter is determined by $=$ Organic Carbon $\times 1.724$

\section{Determination of Total Petroleum Hydrocarbon (TPH):}

Total petroleum hydrocarbon of the soil sample was determined by the method of Intergovernmental Oceanographic Commission (IOC) as described by [24]. Wet sample ( $10 \mathrm{~g}$ dry equivalent by weight) of soil was mixed with anhydrous sodium sulfate $(5 \mathrm{~g})$ in a flask. The soil sample was agitated after the addition of analytical grade $\mathrm{N}$-hexane and gravimetric analysis was then carried out to determine the TPH residual in the treated contaminated soil samples.

\section{Heavy Metal Analysis:}

The heavy metal analysis was carried out by Atomic Absorption Spectrophotometry (AAS). For each of the metal [Iron (Fe), Zinc ( $\mathrm{Zn}), \mathrm{Lead}(\mathrm{Pb}), \mathrm{Cadmium}$ $(\mathrm{Cd})$, Copper $(\mathrm{Cu})$, Chromium $(\mathrm{Cr})$ and Nickel $(\mathrm{Ni})]$, AAS is calibrated using a standard solution of the metal. $5 \mathrm{~g}$ of soil sample was digested in $20 \mathrm{~mL}$ of hydrogen chloride on a heating mantle to dryness. The extract was aspirated directly into the AAS and reagent blank was used to estimate the amount of each metal.

Statistical Analysis: Mean values of all the parameters taken were calculated and factorial analysis of variance (ANOVA) was also determined at 0.05 of the confidence interval. 
Citation: Ayandele, Abiodun A, 2018. Biotreatment of Soil Contaminated with Spent engine Oil by Locally Isolated Microorganisms. Advances in Environmental Biology 12(11): 22-28. DOI:10.22587/aeb.2018.12.11.3

RESULTS AND DISCUSSION

Table 1: Total Heterotrophic Bacteria and Total Hydrocarbon-Degrading Bacteria Counts in Control and Contaminated Soil Samples

\begin{tabular}{|c|c|c|c|c|}
\hline $\begin{array}{c}\text { Sampling } \\
\text { Months }\end{array}$ & $\begin{array}{c}\text { Control Plot } \\
\left.\text { TFU } \times 10^{5}\right)\end{array}$ & $\begin{array}{c}\text { Contaminated Plot } \\
\text { Total Heterotrophic count }( \\
\left.\text { CFU } \times 10^{3}\right)\end{array}$ & $\begin{array}{c}\text { Total Oil Degraders Count }( \\
\left.\text { CFU } \times 10^{5}\right)\end{array}$ \\
\hline April & 248 & 95 & 275 & 180 \\
\hline June & 275 & 86 & 197 & 376 \\
\hline August & 280 & 74 & 248 & 473 \\
\hline October & 225 & 65 & 297 & 415 \\
\hline December & 175 & 47 & & 325 \\
\hline
\end{tabular}

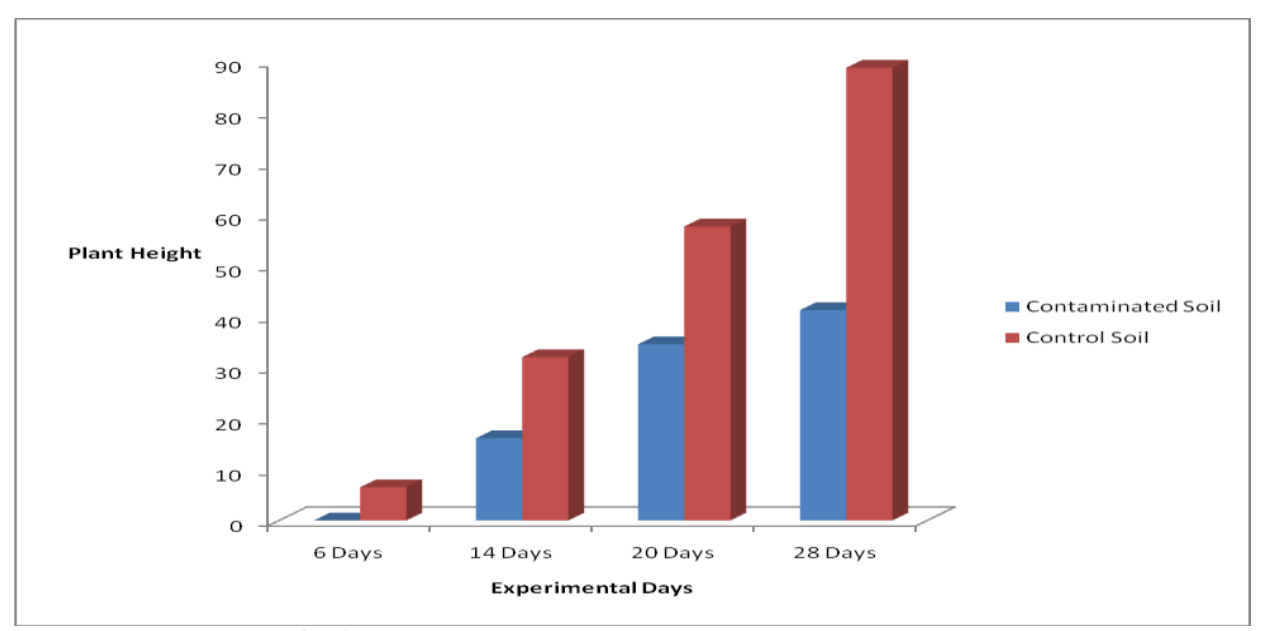

Fig. 1: Maize Plant Height on Contaminated and Control Plots

Table 2: Physicochemical Analysis of Soil Samples with Different Treatments

\begin{tabular}{|c|c|c|c|c|c|c|c|c|c|}
\hline \multirow{2}{*}{ Parameter } & \multirow{2}{*}{ Week } & \multicolumn{8}{|c|}{ Samples } \\
\hline & & $\begin{array}{l}\text { Control } 1 \\
\text { (PC) }\end{array}$ & $\begin{array}{l}\text { Control } 2 \\
\text { (NC) }\end{array}$ & $\begin{array}{l}\text { P. aeruginosa } \\
\text { (BS1) }\end{array}$ & $\begin{array}{l}\text { Flavobacterium sp. } \\
\text { (BS2) }\end{array}$ & $\begin{array}{l}\text { Micrococcus } \\
\text { sp. (BS3) }\end{array}$ & $\begin{array}{l}\text { Fusarium } \\
\text { sp. (FS1) }\end{array}$ & $\begin{array}{l}\text { Rhizopus } \\
\text { sp (FS2) }\end{array}$ & $\begin{array}{l}\text { Penicillium sp. } \\
\text { (FS3) }\end{array}$ \\
\hline \multirow{3}{*}{$\mathrm{pH}$} & 1 & $6.4^{*}$ & 7.2 & $6.8^{*}$ & $6.7^{*}$ & $6.6 *$ & 6.9 & $6.5 *$ & 6.4 \\
\hline & 5 & 6.8 & 7.3 & 7.1 & 6.9 & 6.8 & 6.9 & 6.8 & 6.5 \\
\hline & 10 & 6.75 & 7.4 & 7.4 & 6.95 & 6.9 & 6.95 & 6.9 & $6.7 *$ \\
\hline \multirow{3}{*}{ K } & 1 & $0.48^{*}$ & 0.33 & 0.35 & 0.36 & 0.4 & 0.45 & 0.37 & 0.38 \\
\hline & 5 & 0.41 & 0.29 & $0.31^{*}$ & $0.32 *$ & $0.37 *$ & $0.39^{*}$ & $0.33^{*}$ & $0.35^{*}$ \\
\hline & 10 & 0.39 & $0.23 *$ & 0.27 & 0.28 & 0.32 & 0.3 & 0.28 & 0.29 \\
\hline \multirow{3}{*}{$\mathrm{N}$} & 1 & 0.109 & 1.555 & 1.5 & 1.485 & 1.425 & 1.4 & 1.385 & 1.411 \\
\hline & 5 & $0.097 *$ & $1.041 *$ & $1.01 *$ & $0.999 *$ & $0.443 *$ & $0.802 *$ & $0.785^{*}$ & $0.825 *$ \\
\hline & 10 & 0.082 & 0.963 & 0.721 & 0.476 & 0.125 & 0.576 & 0.426 & 0.346 \\
\hline \multirow{3}{*}{$\mathrm{Mg}$} & 1 & 0.032 & 0.028 & 0.035 & 0.043 & 0.038 & 0.040 & 0.03 & 0.038 \\
\hline & 5 & 0.03 & 0.024 & $0.03 *$ & $0.036^{*}$ & $0.033^{*}$ & $0.033^{*}$ & 0.03 & $0.032 *$ \\
\hline & 10 & $0.025^{*}$ & $0.017 *$ & 0.022 & 0.025 & 0.028 & 0.027 & $0.024 *$ & 0.025 \\
\hline \multirow{3}{*}{$\mathrm{Ca}$} & 1 & 20.1 & 25.22 & 20.46 & 23.5 & 20.15 & 21.12 & 22.6 & 22.46 \\
\hline & 5 & $19.3 *$ & $23.35 *$ & $17.5^{*}$ & $21.75^{*}$ & $18.92 *$ & $19.8^{*}$ & $21.2 *$ & $19.45 *$ \\
\hline & 10 & 17.45 & 19.87 & 14.15 & 18.67 & 14.74 & 15.98 & 18.64 & 15.4 \\
\hline \multirow{3}{*}{ AVP } & 1 & 2.5 & 3.1 & 2.75 & 2.65 & 2.6 & 3.0 & 2.9 & 2.7 \\
\hline & 5 & $2.3 *$ & 3.1 & $2.65^{*}$ & $2.1 *$ & $2.15^{*}$ & $2.65^{*}$ & $2.7 *$ & $2.55^{*}$ \\
\hline & 10 & 1.97 & $2.75^{*}$ & 2.42 & 1.85 & 1.85 & 2.15 & 2.33 & 2.15 \\
\hline
\end{tabular}

a) Values = mean.

(b)*mean significant to others in the column of the same parameters at $p \leq 0.05$

Table 3: Values of TPH, Organic Carbon and Organic Matter in Various Soil Samples Treatment inside $\quad$ Seed Bags

\begin{tabular}{|c|c|c|c|c|c|c|c|c|c|}
\hline \multirow{2}{*}{ Parameter } & \multirow{2}{*}{ Week } & \multicolumn{8}{|c|}{ Samples } \\
\hline & & Control 1 & Control 2 & P. aeruginosa & Flavobacterium sp. & $\begin{array}{c}\text { Micrococcus } \\
\text { sp. }\end{array}$ & $\begin{array}{c}\text { Rhizopus } \\
\text { sp. }\end{array}$ & $\begin{array}{c}\text { Fusarium } \\
\text { sp }\end{array}$ & $\begin{array}{c}\text { Penicillium } \\
\text { sp. }\end{array}$ \\
\hline \multirow{4}{*}{$\begin{array}{l}\text { Total Petroleum } \\
\text { Hydrocarbons } \\
\text { (PPM) }\end{array}$} & 0 & 2.41 & 20.29 & 20.29 & 20.29 & 20.29 & 20.29 & 20.29 & 20.29 \\
\hline & 3 & 2.36 & 19.21 & 13.25 & 13.02 & 15.36 & 16.19 & 9.28 & 16.46 \\
\hline & 6 & 2.28 & 19.01 & 10.2 & 10.42 & 12.46 & 13.12 & 5.75 & 9.56 \\
\hline & 10 & 2.09 & 18.78 & 2.19 & 3.18 & 4.1 & 4.12 & 2.25 & 3.87 \\
\hline \multirow{4}{*}{$\begin{array}{c}\% \text { Organic } \\
\text { Carbon }\end{array}$} & 0 & 1.09 & 15.55 & 15.55 & 15.55 & 15.55 & 15.55 & 15.55 & 15.55 \\
\hline & 3 & 1.05 & 13.69 & 10.28 & 10.13 & 11.83 & 11.7 & 7.15 & 10.67 \\
\hline & 6 & 0.97 & 10.41 & 7.85 & 8.02 & 9.98 & 10.1 & 4.43 & 7.26 \\
\hline & 10 & $0.2^{*}$ & $5.17^{*}$ & $1.69^{*}$ & $2.45^{*}$ & $3.54 *$ & $3.4^{*}$ & $1.73^{*}$ & $2.67 *$ \\
\hline \multirow{3}{*}{$\begin{array}{c}\% \text { Organic } \\
\text { Matter }\end{array}$} & 0 & 1.88 & 26.81 & 26.81 & 26.81 & 26.81 & 26.81 & 26.81 & 26.81 \\
\hline & 3 & 1.81 & 23.6 & 17.72 & 17.5 & 20.39 & 20.17 & 12.33 & 18.39 \\
\hline & 6 & 1.67 & 17.95 & 13.53 & 13.83 & 17.21 & 17.41 & 7.64 & 12.5 \\
\hline
\end{tabular}


Citation: Ayandele, Abiodun A, 2018. Biotreatment of Soil Contaminated with Spent engine Oil by Locally Isolated Microorganisms. Advances in Environmental Biology 12(11): 22-28. DOI:10.22587/aeb.2018.12.11.3

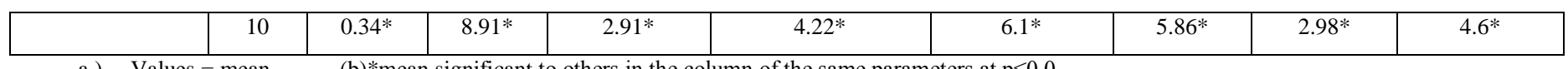

a.) Values = mean

(b)*mean significant to others in the column of the same parameters at $\mathrm{p} \leq 0.0$

Table 4: Heavy Metal Analysis of the Treatments during the Experimental Period

\begin{tabular}{|c|c|c|c|c|c|c|c|c|c|}
\hline \multirow{2}{*}{ Parameter } & \multirow{2}{*}{ Week } & \multicolumn{8}{|c|}{ Samples } \\
\hline & & Control 1 & Control 2 & P. aeruginosa & $\begin{array}{c}\text { Flavobacterium } \\
\text { sp. }\end{array}$ & Micrococcus sp. & $\begin{array}{l}\text { Fusarium } \\
\text { sp. }\end{array}$ & $\begin{array}{l}\text { Rhizopus } \\
\text { sp }\end{array}$ & Penicillium sp. \\
\hline \multirow{3}{*}{$\mathrm{Fe}$} & 1 & $0.016^{*}$ & 0.096 & 0.026 & 0.036 & 0.025 & 0.021 & 0.018 & 0.019 \\
\hline & 5 & 0.012 & $0.07 *$ & 0.021 & $0.029 *$ & $0.018^{*}$ & $0.017 *$ & 0.014 & $0.015^{*}$ \\
\hline & 10 & 0.009 & 0.045 & $0.015^{*}$ & 0.018 & 0.01 & 0.011 & $0.009 *$ & 0.011 \\
\hline \multirow{3}{*}{$\mathrm{Zn}$} & 1 & 0.28 & 0.45 & 0.3 & 0.33 & 0.3 & 0.35 & 0.38 & 0.37 \\
\hline & 5 & $0.17 *$ & $0.39 *$ & 0.25 & $0.28 *$ & 0.25 & $0.29 *$ & $0.3 *$ & $0.31 *$ \\
\hline & 10 & 0.11 & 0.27 & $0.19 *$ & 0.21 & $0.19 *$ & 0.2 & 0.22 & 0.26 \\
\hline \multirow{3}{*}{$\mathrm{Pb}$} & 1 & 0.04 & $0.35^{*}$ & $0.28 *$ & 0.31 & $0.34 *$ & 0.32 & 0.32 & 0.36 \\
\hline & 5 & 0.03 & 0.38 & 0.31 & 0.32 & 0.36 & 0.31 & $0.29 *$ & $0.34 *$ \\
\hline & 10 & 0.02 & 0.39 & 0.33 & $0.34 *$ & 0.37 & $0.29 *$ & 0.26 & 0.29 \\
\hline \multirow{3}{*}{$\mathrm{Cd}$} & 1 & $0.09 *$ & 0.15 & 0.095 & 0.097 & 0.095 & 0.09 & 0.09 & 0.092 \\
\hline & 5 & 0.045 & 0.13 & $0.054 *$ & $0.07^{*}$ & $0.065^{*}$ & $0.06^{*}$ & 0.08 & 0.079 \\
\hline & 10 & 0.026 & 0.1 & 0.031 & 0.043 & 0.031 & 0.035 & $0.065^{*}$ & $0.054 *$ \\
\hline \multirow{3}{*}{$\mathrm{Cu}$} & 1 & 0.17 & 0.26 & $0.21 *$ & 0.2 & 0.23 & 0.22 & 0.21 & 0.22 \\
\hline & 5 & $0.15 *$ & $0.24^{*}$ & 0.17 & $0.17^{*}$ & 0.2 & 0.19 & 0.19 & 0.18 \\
\hline & 10 & 0.13 & 0.21 & 0.12 & 0.13 & $0.16^{*}$ & $0.11 *$ & $0.16^{*}$ & $0.13^{*}$ \\
\hline \multirow{3}{*}{$\mathrm{Cr}$} & 1 & 0.15 & 0.25 & 0.17 & 0.15 & 0.16 & 0.14 & 0.19 & 0.15 \\
\hline & 5 & 0.14 & $0.23^{*}$ & $0.13^{*}$ & $0.11^{*}$ & $0.12^{*}$ & $0.11^{*}$ & $0.17 *$ & $0.13^{*}$ \\
\hline & 10 & $0.11 *$ & 0.19 & 0.08 & 0.06 & 0.07 & 0.07 & 0.11 & 0.09 \\
\hline \multirow{3}{*}{$\mathrm{Ni}$} & 1 & 0.15 & 0.25 & 0.17 & 0.15 & 0.16 & 0.14 & 0.19 & 0.18 \\
\hline & 5 & 0.14 & $0.21^{*}$ & $0.13^{*}$ & $0.11^{*}$ & $0.13^{*}$ & $0.11^{*}$ & $0.15^{*}$ & $0.15^{*}$ \\
\hline & 10 & $0.13^{*}$ & 0.19 & 0.08 & 0.08 & 0.09 & 0.07 & 0.11 & 0.1 \\
\hline
\end{tabular}

a.) Values = mean.

(b) *mean significant to others in the column of the same parameters at $\mathrm{p} \leq 0.05$

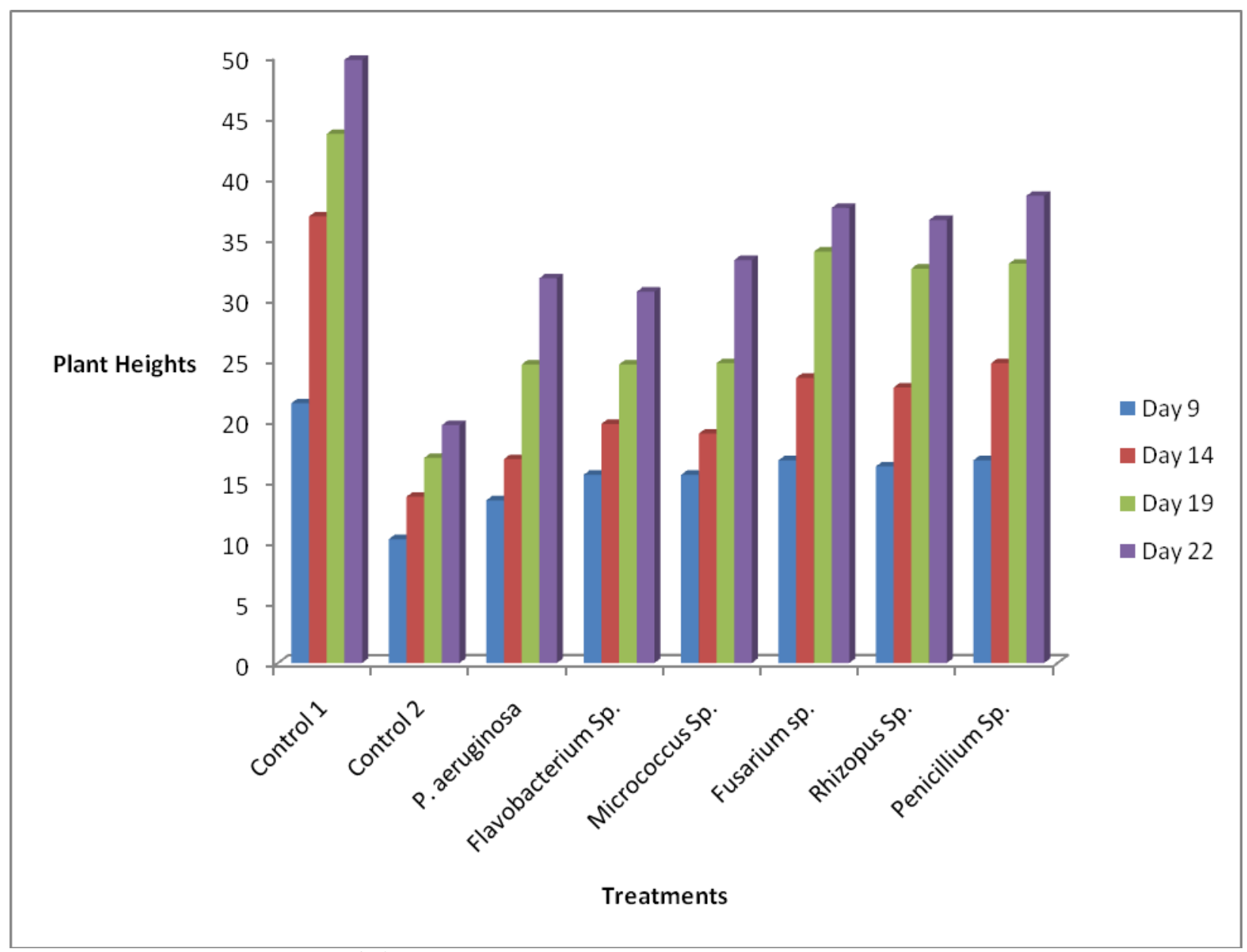

Fig 2: Maize Plant Heights with Different Treatment in Seed Bags

Isolation of both total heterotrophic and degraders counts was carried out for nine months on both contaminated and control plots soil samples. Table 1 shows the counts of total heterotrophic and oil-degrading bacteria on both the uncontaminated (control) and contaminated plots. There was a gradual increase in the heterotrophic count on the control plot but as the experimental months increased, the counts started increasing from $248 \mathrm{CFU} \times 10^{5}$ in the first month to 280 $\mathrm{CFU} \times 10^{5}$ (fifth month) but as the month progresses, it started to reduce till the last month but the counts of heterotrophic bacteria was high in the contaminated soil samples at the beginning of the experiment $\left(275 \mathrm{CFU} \times 10^{3}\right)$ but as the month progressed, there was a reduction in the count but later increased to $297 \mathrm{CFU} \times$ $10^{3}$ in the last month. There was a decrease in the total oil degraders in the control plot from $95 \mathrm{CFU} \times 10^{3}$ to $47 \mathrm{CFU} \times 10^{3}$ in the control plot, while oil degraders 
Citation: Ayandele, Abiodun A, 2018. Biotreatment of Soil Contaminated with Spent engine Oil by Locally Isolated Microorganisms. Advances in Environmental Biology 12(11): 22-28. DOI:10.22587/aeb.2018.12.11.3

increased from $180 \mathrm{CFU} \times 10^{5}$ to $473 \mathrm{CFU} \times 10^{5}$ on the contaminated plot by the fifth month but it started to reduce in the seventh month till it has reduced to 325 $\mathrm{CFU} \times 10^{3}$ in the last month of the experiment (Table 1). Increase in the counts of total heterotrophic bacteria count during the rainy season as compared to dry season was observed in this study and this has been previously reported [25]. Similar observation was also reported by Subathra et al. [26] in their work High heterotrophic bacteria counts in the contaminated plots as the experiment progresses have been attributed to the fact that more nutrients are now available for the indigenous bacteria present in the soil due to the breakdown of hydrocarbons to the simpler forms by the oil- degrading bacteria [27]. Increase in the total viable counts of the isolates could also increase with progress in the days of incubation [28], while Rahma \& Rahma [29] also reported that population level of hydrocarbon utilizers and their populations within the microbial community appear to be a sensitive index of environmental exposure to hydrocarbons, while the environmental condition might be another factor affecting the growth of microorganisms in the soil environment. Also, the presence of high numbers of hydrocarbon degraders has been linked to the high availability of nutrients [30; 31]. Studies have also shown that the hydrocarbon degrading microorganisms are always abundant in petroleum hydrocarbon contaminated soils and such soils serve as the good sources for the isolation of hydrocarbon-degrading microorganisms $[32 ; 33 ; 34]$.

Figures 1 and 2 showed the plant heights of maize planted on the contaminated and uncontaminated soil and seed bags. Germination of maize seeds was delayed for the maize planted on the contaminated soil while there was no delay on the maize seeds planted on control plot, which is soil without spent engine oil (Fig 1). On day 6, maize plant height on control plot was $8 \mathrm{~cm}$ while no visible growth was observed on the contaminated plot. By the $28^{\text {th }}$ days, plant heights on control and contaminated plots had increased to $88 \mathrm{~cm}$ and $42 \mathrm{~cm}$ respectively. Heights of maize plants planted inside seed bags containing spent engine oil treated with different microorganisms, control 1 (uncontaminated soil in seed bag) and Control 2 (uncontaminated soil seed bag) were also determined. Control 1 had the highest plant height followed by soil treated with Penicillin sp, soil treated with Rhizopus sp showed the least maize plant height among the treated soil samples while control 2 showed the least plant height (Fig 2) [35; 36]. Delayed in plant germination has been reported by Onwuka et al. [37], while Adenipekun et al. [38] also reported low leaves yield in Corchorus olitorius (L) growing in soil contaminated with spent diesel oil. Reduction in soil quality and crop yield in hydrocarbon contaminated soil has also been reported [39].

Three (3) bacteria namely; Pseudomonas sp, Flavobacterium sp and Micrococcus sp and three fungal isolates (Fusarium sp, Rhizopus sp, and Penicillium sp) were isolated from the soil contaminated with spent engine oil using oil agar medium. [40; 41;42,43] also isolated similar bacteria in their works. Some of the fungi isolated from this study have been reported as hydrocarbons utilizers [44; 45; 46, 47]. Biodegradation abilities of different genera of bacteria and fungi have also been reported [48]. Anthropogenic impacts, such as changes in nutrients composition, also have the potential to directly or indirectly affect the bacterial and fungal composition of the soil [49].

Factorial Analysis of variance (ANOVA) at 5\% confidence interval was used to compare the differences in physico-chemicals parameters, \% OM, \% OC, TPH and Heavy metals analyses of samples treated with different microorganisms during the experimental weeks. There was a significant difference between the parameters observed in this study and the activities of the microbes on the samples. The $\mathrm{pH}$ of all the samples was significantly different as the days progressed, except for the $\mathrm{pH}$ of the Control 2, which showed no significant difference at $\mathrm{pH}$ of 7.2 on week $1,7.3$ on week 5 and a pH of 7.4 on week 10 . There was a significant difference in the potassium level, with the highest level recorded for Control 1 on week 1 (0.48), followed by Fusarium sp. on week 1 with 0.45 (Table 2). Okonokhua et al. [5] reported that there was no significant difference between the $\mathrm{pH}$ of the control and spent oil treated soil in their study while, Shahida et al. [1] reported neutral pH from $7.02-7.5$ at different points and slightly alkaline (8.44) in one point of soil contaminated with hydrocarbons in their study. Nitrogen showed a significant difference among the physicochemical parameters analysed as the weeks of treatment progressed, the highest value of 1.555 was recorded for Control 2 on week 1 and the lowest being 0.082 for the Control 1 on week 10. Micrococcus sp. had the lowest values for nitrogen among the treatments throughout the experimental weeks with the values ranging from 1.425 to 0.125 between Week 1 and Week 10. Significant difference was also observed in the values of Mg and $\mathrm{Ca}$, while there was a significant difference among the parameters tested during the experiments as Average values of Phosphorous (AVP) concentration in the Control 2 was reduced to 1.85 on the tenth week while Flavobacterium sp and Micrococcus sp, had the lowest value of 1.85 on week 10 (Table2). The pH levels of the soil samples increased from acidic to neutral in all the soil samples. $\mathrm{pH}$ of $6.62-7.72$, phosphate of $0.10-0.11 \mathrm{mg} / \mathrm{kg}, \mathrm{Nitrate}$ of $0.22-0.31 \mathrm{mg} / \mathrm{kg}$, $\% \mathrm{TOC}$ of $1.23-3.99 \%$, Potassium of $0.87-0.90 \mathrm{mg} / \mathrm{kg}$ and Nitrogen of $0.06-0.51 \%$ have been reported by Rousk et al. [49] in their study of crude oil degradation by microorganisms in soil composts. Shahida et al. [1] also observed high content of potassium and sodium contents from all the soil samples analysed in their work and low concentrations of available carbon, nitrogen, and phosphorus.

There was a reduction in total petroleum hydrocarbon concentrations in all the treatments with Control 1 having the lowest value of 2.09 followed by $P$. aeruginosa (2.22). Percentage of organic carbon which was the highest (15.55\%) in Control 2 at the beginning of the experiment was low in control 1 from week 1 till the end of the experiment, while reduction in the percentage of organic carbon was observed in the other treatments with $P$. aeruginosa having the lowest value on week 10 of the experiment. The percentage of organic matter was low throughout in Control 1 with the upper limit being 1.88 and the lowest was 0.34 , while 26.81 was the upper limit for the other treatments, while the lowest limit was 2.91 (Table 3). [38] reported increased in the level of \% OC, \% OM, Phosphorus and Potassium after 2 months of biodegradation of soil contaminated with spent and fresh cutting fluids and decrease in total nitrogen and $\mathrm{pH}$. The increase in the percentage of organic carbon and nitrogen of spent engine oil soil in relative to control could be attributed to the effect of spent engine oil [8] while [50] also reported a reduction in nitrogen content on the soil treated with spent lubricant oil. While available carbon, nitrogen, and phosphorus were very low in the study of [1], [51] observed significant increase in the nitrogen and carbon contents in their own study and reported that increase in nitrogen might be due to the increase in atmospheric nitrogen during the degradation process, while carbon increase might be due to the presence of carbons in hydrocarbons.

Rahma \& Rahma [29] reported that nutrient availability is dependent on the nature of the environment sometimes and that nutrients such as nitrogen and phosphorus could be limiting sometimes and thus affecting the biodegradation process. Reduction in Total Petroleum Hydrocarbons (TPH) was observed as the weeks of biodegradation increased, the highest TPH removal was observed in P. aeruginosa (2.19 PPM), followed by Fusarium sp (2.25) while soil treated with Rhizopus sp had the highest TPH content (7.17) at the end of the experiment (Table 3). [52, 53] had reported that TPH removal always increases as the days of incubation increase, while Shukar et al. [53] reported that biodegradation rate of Pseudomonas sp in diesel oil contaminated soil increased as the days of biodegradation increased. [8] also reported an increase in removal of TPH as incubation period is elongated in soil contaminated with used motor oil, while [38] reported reduction in TPH after two (2) months from fresh and spent cutting oil contaminated soil samples.

There was a significant difference in the values of $\mathrm{Fe}, \mathrm{Zn}, \mathrm{Pb}, \mathrm{Cd}, \mathrm{Cu}, \mathrm{Cr}$ and $\mathrm{Ni}$ during the experimental period with control 1 having the lowest values on week 10 for $\mathrm{Zn}(0.11), \mathrm{Pb}(0.02)$ and $\mathrm{Cd}(0.026)$ while both the control 1 and Rhizopus sp. have the lowest value for $\mathrm{Fe}$, control 2 had the lowest value for $\mathrm{Cr}$ (0.06) but soil sample treated with Fusarium sp. had the lowest value for $\mathrm{Cu}(0.11)$ and $\mathrm{Ni}(0.07)$ on week 10 of the experiment. Flavobacterium sp. had the lowest value of $\mathrm{Cr}$ after treatment when it was compared to the initial values at the beginning of the experiments (Table 4).There was a gradual and significant reduction in the content of heavy metals present in the soil contaminated with spent engine oil in relative to the control soils (Table 4). [52] also observed reduction in $\mathrm{Mn}, \mathrm{Pb}, \mathrm{Ni}$, and $\mathrm{Cu}$ in soil contaminated with fresh and spent cutting fluid after 2 months even in the control. While [54; 55] reported a gradual decrease in the different metals analysed in the spent oil contaminated site as the experimental days progressed.

\section{CONCLUSION}

The results obtained in this study showed that all organisms isolated from the contaminated soil can be used for biodegradation process. Reduction in total petroleum hydrocarbons and heavy metals present in the contaminated soil samples was observed in the biodegradation experiment with these organisms. Contribution to Knowledge

This study has showed that indigenous microorganisms have abilities to remediate soil contaminated with spent engine oil and that this reclaimed site can be used for maize cultivation.

\section{REFERENCES}

[1] Shahida AA, S Sambo and IA Salau, 2015. Biodegradation of used engine oil by fungi isolated from mechanic workshop soils in Sokoto metropolis, Nigeria. Sky Journal of Soil Science and Environmental Management. 4 (6): 54-69. 
[2] Mark, H. F, D. F, Othmer, C.G, Overberger, and G. T, Seasbury, 1982. Kirk-Othmer Encyclopedia of Chemical Technology 14: 484-501/

[3] Nwinyi, O. C., Ajaja, O., Nwinyi, C. 2014. Growth dynamics of bacteria isolated from spent engine oil contaminated tropical soil. Res. J. Environ. Earth Sci. 6: 430-436.

[4] Yan, L, Sinkko, H, Panttiner, P, Lindstrom, K. 2016. Characterization of successional changes in bacteria community composition during bioremediation of used motor-oil contaminated soil in boreal climate. Sci. Total Environ. 542: 817-825.

[5] Okonokhua, B. O, B, Ikhajiagbe, G. O, Anoliefo, and J. O, Emede, 2007. The effect of spent engine oil on soil properties and growth of maize (Zea may L). J. Appl. Sci. Environ. Mgt. 11 (3): 147 - 152.

[6] Falciglia, P. P, Maddalena, R., Mancuso, G, Messina, V, Vanliasindi, F. G. H. 2016. Lab scale investigation on remediation of diesel contaminated aquier. J. Environ. Manage. 167: 196-205.

[7] Mohd, M. B, S. S, Shiu, Y, Mohammad, and R. N, Shukai, 2011. Remediation of hydrocarbon contaminated soil through microbial degradation - FTIR based production. Advances in Applied Science Research 2 (2): 321-326.

[8] Abdulsalam, S, S. S, Adefila, I. M, Bugaje, and S. C, Ibrahim, 2012. Bioremediation of soil contaminated with used motor oil in a closed system. J. Bioremediation and Biodegradation 3(12): 1-7.

[9] Ugoh, S. S, and L. U, Moneke, 2011. Isolation of bacteria from engine oil contaminated soils in Auto mechanic workshops in Gwagwalada, Abuja, FCT. Nigeria Academic Arena 3(5): 28-38.

[10] Osaigbovo, A. U, Lawogbomo, K.E., Agele, S. O. 2013. Effects of spent engine oil polluted soil and organic amendment on soil chemical properties, microflora on growth and herbage of Telfairia occidentalis (book F). Bayero J. Pure Appl. Sci. 6: 72-78.

[11] Atlas, M. A., and R, Bartha, 1992. Hydrocarbon biodegradation and oil spill bioremediation. In: Marshall KC (ed). Advances in Microbial Ecology, Vol 12. Plenum Press, New York. Pp 287-338.

[12] Kastner, M, Mitner, A. 2016. Application of compost for effective bioremediation of organic contaminants and pollutants in soil. Appl. Microbiol. Biotechnol. 100: 3433-3449.

[13] Nwankwegu, A.S, Onwosi, C. O. 2017. Bioremediation of gasoline contaminated agricultural soil by augmentation. Environ. Tech, Innovation, 77: 1-11.

[14] Namkoong, W., E. Y, Hwang, J. S, Park, J. Y, Choi, 2002. Bioremediation of diesel-contaminated soil with composting. Environ. Pollut. 119: 23-31.

[15] Boonchan, S, M. C, Britz, and G. A, Stanley, 2000. Degradation and mineralization of high molecular weight polycyclic aromatic hydrocarbons by defined fungal-bacterial co cultures. Appl. Environ. Microbiol. 66 (3): 1007-1019.

[16] Al-Jawhari, I. F. H, 2014. Ability of some fungi in biodegradation of petroleum hydrocarbons. Journal of Applied and Environmental Monitoring 2 (2): 4652.

[17] Lorch, H.J, G, Benckieser, J. C. G, Otfous, 1995. Basic methods for counting microorganisms in soils and water. In: Methods in Applied Soil Microbiology and Biochemistry. Academic Press, New York, Pp. 146-161.

[18] Adebusoye, J. R, M. O, Ilori, O. O, Amund, O. D, Teniola, S. O, Olatope, 2007. Microbial degradation of petroleum hydrocarbons in a polluted tropical stream. World Journal of Microbiology and Biotechnology, 23(8): 1149-1159.

[19] Holt, J. G, N. R, Krieg, P. H. A, Sneath, J. T, Stanley, and S. T, Williams, 1994. Bergey's Manual of Determinative Bacteriology. Williams and Wilkins, Baltimore

[20] Mackie, L, and M, McCartney, 1999. Practical medical Microbiology, $14^{\text {th }}$ Ed.Harcourt brace and Company limited.

[21] El Mahi, Y. I. S, Ibrahim, H. M, Abdelmajid, and A.M, Eltilib, 1987. A simple method for determination of calcium and magnesium carbonate in soils. Soil Sci. Soc. Am. J. 51:1152-1155.

[22] Sankaram, R. A., R, Musinger and R, Mckinney, 1982. Modern Kjedahl system, Int. Laboratory 12, 7, 38-41.

[23] Olsen, S. R, C. V, Cole, F. S, Watnab, and L. A, Decan, 1954. Estimation of available phosphorus in soil by extra action with sodium bicarbonate. U. S. Department of Agriculture. Pp 939.

[24] Chukwujindu, M. A, E. S, Iwegbue, E, Williams and G. E, Nwajei, 2008.Characteristic levels of Total petroleum Hydrocarbons in Soil Profiles of Automobile Mechanic waste Dumps. International Journal of Soil Science, 3: 48-51.

[25] Zhan, A, Y, Zhang, T, Dung, X, Lin, X, Su, 2015. Response of the microbial community to seasonal groundwater level fluctuations in petroleum hydrocarbons contaminated groundwater. Environ. Sci. Pollut. Res. 22: 10094-10106.

[26] Subathra, M. K.,G., Immanuel, and A. H,Suresh, 2013. Isolation and identification of hydrocarbon degrading bacteria from Ennore Greek. Bioinformation 9(3): 150-157.

[27] Okerentugba, P. O., and O. U, Ezeronye, 2003. Petroleum degrading potential of single and mixed microbial culture isolated from rivers and refinery effluents in Nigeria. Afr. J. Biotechnol. 2 (9): 288-292.

[28] Nwinyi, O. C., Olutubo, V. R. 2014. Biodegradation of kerosene by soil bacterial species from contaminated site. Covenant J. Phys. Life Sci. 2: 14-23.

[29] Rahma, K. S. M., T, Rahma, P, Lakshmanaperumalsang, and I. M, Banat, 2002. Occurrence of crude oil degrading bacteria in gasoline and diesel station soils. J. Basic Microbiol. 42: 284-291.

[30] Atlas, R. M. 1995. Pathway of the hydrocarbon. In Petroleum Microbiology. Macmillian Publishing Company, New York: 1-15.

[31] Ijah, U. J. J. and C. N, Okang, 1993. Petroleum degrading capabilities of bacteria isolated from soil. West Afr. J. of Biol. And Appl. Chem. 38 (1-4): 9 -15.

[32] Ekhause, F.O., and J, Nkwell, 2011. Microbiological and physicochemical analyses of SP soil contaminated from major motor mechanic workshops in Benin city metropolis, Edo sate, Nigeria. J. Appl. Sci. Environ. Manag. 9: 103-106.

[33] Maddela, N.R., R, Burgos, V, Kadiyala, H. R, Carrion, M, Bangesppogari, 2016. Removal of petroleum hydrocarbons from crude oil in solid and slurry phase by mixed soil microorganisms isolated from Ecuadorian oil fields. International Biodeterioration and Biodegradation 108: 85-90.

[34] Maddela, N.R., L, Scalvenzi, K, Venkateswarlu, 2017. Microbial degradation of total petroleum hydrocarbons in crude oil: a field-scale study at the lowland rainforest of Ecuador. Environmental Technology 38(20): 2543-2350.

[35] Ekundayo, E. O., T. O, Emede, and D, Osayande, 2001. Effects of crude oil spillage on growth and yield of maize (Zea mays L.) in soils of Midwestern Nigeria. Plant, Food and Human Nutri. 56: $313-324$.

[36] Nwite, J. N., and M. O, Alu, 2015. Effects of different levels of spent engine oil on soil Abakaliki, South Eastern, Nigeria. Journal of Soil Science and Environmental Managem

[37] Onwuka, M. I., V. O, Chude, and G. C, Ogwuegbu, 2012. Remediation of spent engine oil maize growth. Nig. J. Soil Sci. 22 (2): 245.

[38] Adenipekun, C. O., O. O, Ayanleye, and O. J, Oyetunji, 2013. Bioremediation of soil contaminated by spent diesel oil using Pleurotus pulmonarius fries (Quelet) and its effects on the growth of Corchorus olitorius (L). Journal of Applied Biosciences 68: 5366-5377.

[39] Adeoye, M. B., M. K. C, Sridhar, O. O, Adeoluwa, and N. A, Akinsuyi, 2005. Evaluation of naturally decomposed solid wastes from municipal dump sites for their manorial value in Southwest Nigeria. J. Sustain. Agric. 26 (4): 142-152.

[40] Khan, J. A. and S. H. A, Rizi, 2011. Isolation and characterization of microorganisms from oil contaminated sites. Adv. Appl. Scien. Res. 2 (3): $455-460$.

[41] Abioye, O. P., P, Agamuthu, and A. R, Abdul-Aziz, 2012. Biodegradation of used motor oil insoil using organic waste. Biotechnology Research International. $1-8$.

[42] Jesubunmi, C. O, 2014. Isolation of oil-degrading microorganisms in spent engine oil -contaminated soil. Journal of Biology, Agricultural and Healthcare. 4 (25): $191-195$.

[43] Ron, E. Z, Rosenberg, E. 2014. Enhanced bioremediation of oil spills in the sea. Curr. Opin. Biotechnol. 27: 191-194.

[44] April, T. M., J. M, Foght, and R. S, Curah, 2000. Hydrocarbon-degrading filamentous fungi isolated from flare pit soils in Northern and Western Canada. Canadian Journal of Microbiology 46 (6): 38-48.

[45] Obire, O. E., C, Anyanwu, and R. N, Okigbo, 2008. Saprophytic and crude oil-degrading fungi from cow dung and poultry droppings as bioremediating agents. International Journal of Agricultural Technology 4 (2): 81-89. 
[46] George-Okafor, U., F, Tasie, and F, Muotoe-Okafor, 2009. Hydrocarbon degradation potential of indigenous fungal isolates from petroleum contaminated soils. Journal of Physical and Applied Sciences, 3: 1-6.

[47] Omotayo, A. E., O. Y, Ojo, and O. O, Amund, 2012. Crude oil degradation by microorganisms in soil compost. Research Journal of Microbiology 7 (4): 209-218.

[48] Ayandele, A. A., O. E, Fagade, and A. A, Adenegan, 2012. Effect of ammonium salts on the biodegradation of used transformer oil using locally isolated microorganisms. Agriculture and Biological Journal of North America 3(3). 131-139.

[49] Rousk, J., P. C, Brokes, and E, Baath, 2009. Contrasting soil pH effects on fungal and bacterial growth suggest functional redundancy in carbon mineralization. Applied Environ. Microbiol. 75: 1589-1596.

[50] Kayode, J., A. A, Oyedeji, and O, Olowoyo, 2009. Evaluation of the effect of pollution with spent lubricant oil on the physical and chemical properties of soil. Pacific J. Sci. Tech. 10 (1): 387-391.

[51] Lovely, C. A., and T. A, Cackette, 2001. Diesel Engine: Environmental Impact and Control. Air and Waste Management Association 57: $805-847$.

[52] Adenipekun, C. O., and O. S, Isikhuemhen, 2008. Bioremediation of engine oil polluted soils by a tropical white rot fungus, Lentinus squarrosulus Mont. (Singer). Pak. J. Biol. Sci. 11 (12): 1634-1637.

[53] Shukar, M. Y., N. A. A, Hassan, A. Z, Jusoh, N, Perumas, N. A, Shamaaan, W. P, MacCormak, and M. A, Syed, 2009. Isolation and characterization of a Pseudomonas diesel-degrading strain from Antartica. J. Environ. Bio. 30 (1): 1-6.

[54] Adenipekun, C. O., A. R, Ipeaiyeda, and A. J, Olayonwa, 2013. Bioremediation of soil contaminated with spent and fresh cutting fluids by Pleurotus pulmonarius (fries) Quelet. African Journal of Biotechnology 12 (42): 6091-6097.

[55] Adams, G. O., P, Tawari-Fafeyin, E, Igelenyah, and E, Odukoya, 2014. Assessment of Heavy metals bioremediation potential of microbial consortia from poultry litter and spent oil contaminated site. International Journal of Environmental Bioremediation and Biodegradation 2(2): 84-92. 